\title{
Genetic and non-genetic factors affecting body weight in Tellicherry goats
}

\author{
A.K. Thiruvenkadan", M. Murugan, K. Karunanithi, J. Muralidharan and K. Chinnamani \\ Mecheri Sheep Research Station, Pottaneri-636 453, Tamil Nadu, India
}

\begin{abstract}
Data on 566 Tellicherry goats, recorded between 1988 and 2007 were used to study the effect of nongenetic factors on body weight and daily gain from birth to 12 months of age. The least-squares means for body weight at birth and at 12 months of age were $2.17 \pm 0.03$ and $18.78 \pm 0.44 \mathrm{~kg}$, respectively. The preand post-weaning average daily weight gains were $72.41 \pm 1.68$ and $37.46 \pm 1.49 \mathrm{~g}$, respectively, and the associated growth efficiencies were $3.11 \pm 0.08$ and $1.34 \pm 0.05$, respectively. Significant differences associated with the year of kidding were observed in body weight, weight gain and efficiency in weight gain at different stages of growth. Growth rate of kids born between December and February was relatively slower than those born in other months and this can result from seasonal changes and suggests that it is necessary to plan the kidding season rationally by controlling the oestrus and mating time. The kids born as twin had lower birth weight and slower early growth rate than those born as single but had a higher postweaning growth rate. The heritabilities of different traits were moderate to high, except for birth weight, which was of low heritability. The phenotypic and genetic correlations among the different body weights were positive and low to high in magnitude.
\end{abstract}

Keywords: Breed, genetics, growth, heritability, live weight, goat

\#Corresponding author. E-mail: drthirusiva@yahoo.com

\section{Introduction}

Growth potential of kids is one of the most important traits in genetic improvement schemes for chevon production. A number of non-genetic factors affects these growth traits and directly obscures recognition of genetic potential. Hence, the performance records of an animal should be corrected for classifiable non-genetic sources of variation, which is essential for obtaining precise estimates of genetic parameters and breeding values so that breeding animals with the potential genetic merit can be identified and selected for further genetic improvement. Tellicherry goats are one among the recognised breeds of goat in India and is widely distributed in Malabar region of Kerala (Acharya, 1982) and also reared in different places of Tamil Nadu. This breed is considered as a unique genotype exhibiting higher multiple birth percentages and higher milk yields. Studies on performance of Tellicherry goats in their native environment have been reported (Mukundan et al., 1980; Acharya, 1982) and in Tamil Nadu (Sivakumar \& Thiagarajan, 1999; Thiruvenkadan et al., 2007). However, these studies were based on fewer numbers of observations and there have not been a systematic study on the influence of non-genetic factors on body weight at specific feeding and management conditions. Hence, this study was conducted to estimate the non-genetic influences on body weight of Tellicherry goats under prevailing natural and ecological conditions in Tamil Nadu, India, and to estimate the genetic parameters for different traits, which is needed for suitable selection and breeding plans.

\section{Material and Methods}

The data on the body weight of 566 Tellicherry goats, maintained at Mecheri Sheep Research Station Pottaneri, Tamil Nadu, India were collected over a period of 20 years (1988 - 2007). The body weights at different ages (i.e. at birth and at three, six, nine and 12 months) were recorded. The average daily gains in live weights from birth until weaning (WADG) and from weaning until the age of 12 months (PADG) were estimated. The efficiency of growth was assessed as the gain in body weight per $\mathrm{kg}$ of initial weight (Mandal et al., 2003). The data were classified according to period, season, parity of dam, type of birth and sex. The years of kidding were divided into five periods. The data were analysed using a mixed-model leastsquares analysis of fitting constants (Harvey, 1990). The variance and covariance components of growth traits were estimated by fitting a series of univariate animal models using a derivative free REML algorithm 
(DFREML, Meyer, 2000).

\section{Results and Discussion}

The least-squares means ( \pm s.e.) for body weight at different ages are presented in Table 1 . The overall least-squares means for kid weights at the different ages were within the range of values observed by Mukundan et al. (1980), Acharya (1982), Sivakumar \& Thiagarajan (1999) and Thiruvenkadan et al. (2007). The kids born in the south-west monsoon season had higher body weights than those born in other seasons and they were significantly higher at three, nine and 12 months of age. Comparison of the least-squares means for kids' weight at different age showed that the difference between male and female kids increased from $0.21 \mathrm{~kg}$ at birth to $1.42 \mathrm{~kg}$ at 12 months of age. Most of the environmental factors (period, parity, season, type of birth and sex of the kid) had significant to highly significant effects on body weights at different ages. These factors were also proven to be important in other studies on kids of different breeds (Bobhate et al., 2003; Yadav et al., 2003; Sharma \& Pathodiya, 2006). The significant differences in body weight among kids born in different periods may be attributed to differences in management, selection of bucks and environmental conditions such as the ambient temperature, humidity, rainfall, etc.

Table 1 Least-squares means ( \pm s.e.) of body weight $(\mathrm{kg})$ of Tellicherry goats at different age groups

\begin{tabular}{|c|c|c|c|c|c|}
\hline Effect & Birth & 3 months & 6 months & 9 months & 12 months \\
\hline Overall & $2.17 \pm 0.03(566)$ & $8.71 \pm 0.15(485)$ & $12.05 \pm 0.19(411)$ & $15.09 \pm 0.26(358)$ & $18.78 \pm 0.44(304)$ \\
\hline Period & $* *$ & $* *$ & $* *$ & $* *$ & $* *$ \\
\hline $\mathrm{P}_{1}(1988-1991)$ & $2.18^{\mathrm{b}} \pm 0.09(28)$ & $10.03^{\mathrm{b}} \pm 0.51(21)$ & $13.40^{\mathrm{b}} \pm 0.64(18)$ & $16.07^{\mathrm{b}} \pm 0.86(16)$ & $18.53^{\mathrm{b}} \pm 1.40(15)$ \\
\hline $\mathrm{P}_{2}(1992-1995)$ & $2.15^{\mathrm{a}} \pm 0.06(62)$ & $7.66^{\mathrm{a}} \pm 0.30(56)$ & $11.25^{\mathrm{a}} \pm 0.36(54)$ & $13.43^{\mathrm{a}} \pm 0.46(52)$ & $17.72^{\mathrm{ab}} \pm 0.73(51)$ \\
\hline $\mathrm{P}_{3}(1996-1999)$ & $2.23^{\mathrm{b}} \pm 0.04(137)$ & $10.59^{\mathrm{b}} \pm 0.22(121)$ & $14.56^{\mathrm{C}} \pm 0.26(117)$ & $18.11^{b} \pm 0.35(113)$ & $22.61^{\mathrm{c}} \pm 0.57(104)$ \\
\hline $\mathrm{P}_{4}(2000-2003)$ & $2.24^{\mathrm{b}} \pm 0.03(208)$ & $7.67^{\mathrm{a}} \pm 0.17(179)$ & $10.53^{\mathrm{a}} \pm 0.23(146)$ & $13.79^{\mathrm{a}} \pm 0.31(122)$ & $17.29^{\mathrm{a}} \pm 0.54(98)$ \\
\hline$P_{5}(2004-2007)$ & $2.07^{\mathrm{a}} \pm 0.04(131)$ & $7.59^{a} \pm 0.22(108)$ & $10.52^{\mathrm{a}} \pm 0.31(76)$ & $14.05^{\mathrm{a}} \pm 0.46(55)$ & $17.74^{\mathrm{ab}} \pm 0.88(36)$ \\
\hline Season & & $* *$ & & $* *$ & $* *$ \\
\hline $\begin{array}{c}\text { Winter (Dec. to } \\
\text { Feb.) }\end{array}$ & $2.25 \pm 0.04(179)$ & $7.99^{\mathrm{a}} \pm 0.21(166)$ & $11.59 \pm 0.26(151)$ & $14.39^{\mathrm{a}} \pm 0.36(128)$ & $17.57^{\mathrm{a}} \pm 0.62(104)$ \\
\hline $\begin{array}{l}\text { Summer (Mar. } \\
\text { to May) }\end{array}$ & $2.12 \pm 0.05(112)$ & $9.01^{\mathrm{b}} \pm 0.26(95)$ & $12.43 \pm 0.35(72)$ & $15.18^{\mathrm{bc}} \pm 0.47(61)$ & $18.46^{\mathrm{a}} \pm 0.79(53)$ \\
\hline $\begin{array}{l}\text { South-west } \\
\text { monsoon (June } \\
\text { to Aug.) }\end{array}$ & $2.16 \pm 0.05(98)$ & $9.66^{\mathrm{b}} \pm 0.27(80)$ & $12.40 \pm 0.34(71)$ & $16.11^{\mathrm{b}} \pm 0.44(69)$ & $20.97^{\mathrm{b}} \pm 0.71(67)$ \\
\hline $\begin{array}{l}\text { North-east } \\
\text { monsoon (Sep. } \\
\text { to Nov.) }\end{array}$ & $2.18 \pm 0.04$ (177) & $8.17^{\mathrm{a}} \pm 0.21(144)$ & $11.79 \pm 0.26(117)$ & $14.68^{\mathrm{ac}} \pm 0.36(100)$ & $18.11^{\mathrm{a}} \pm 0.62(80)$ \\
\hline Type of birth & $* *$ & $* *$ & $* *$ & $* *$ & $* *$ \\
\hline Single & $2.34^{\mathrm{b}} \pm 0.03(324)$ & $9.16^{\mathrm{b}} \pm 0.18(281)$ & $12.97^{\mathrm{b}} \pm 0.23(241)$ & $16.13^{\mathrm{b}} \pm 0.31(212)$ & $19.68^{\mathrm{b}} \pm 0.54(179)$ \\
\hline Multiple born & $2.01^{\mathrm{a}} \pm 0.03(242)$ & $8.25^{a} \pm 0.19(204)$ & $11.14^{\mathrm{a}} \pm 0.24(170)$ & $14.05^{\mathrm{a}} \pm 0.32(146)$ & $17.88^{\mathrm{a}} \pm 0.52(125)$ \\
\hline Sex of the kid & $* *$ & $* *$ & $* *$ & $* *$ & $* *$ \\
\hline Male & $2.28^{\mathrm{b}} \pm 0.03(289)$ & $9.27^{\mathrm{b}} \pm 0.18(251)$ & $12.57^{\mathrm{b}} \pm 0.24(210)$ & $15.75^{\mathrm{b}} \pm 0.32(178)$ & $19.49^{\mathrm{b}} \pm 0.54(139)$ \\
\hline Female & $2.07^{\mathrm{a}} \pm 0.03(277)$ & $8.15^{\mathrm{a}} \pm 0.19(234)$ & $11.53^{\mathrm{a}} \pm 0.24(201)$ & $14.43^{\mathrm{a}} \pm 0.32(180)$ & $18.07^{\mathrm{a}} \pm 0.53(165)$ \\
\hline Parity & & $* *$ & $* *$ & $*$ & \\
\hline First & $2.06 \pm 0.04(175)$ & $8.05^{\mathrm{a}} \pm 0.20(151)$ & $11.59^{\mathrm{a}} \pm 0.25(130)$ & $14.96^{\mathrm{b}} \pm 0.34(113)$ & $18.14 \pm 0.58(94)$ \\
\hline Second & $2.18 \pm 0.04(131)$ & $8.57^{\mathrm{a}} \pm 0.23(118)$ & $11.72^{\mathrm{a}} \pm 0.28(101)$ & $15.02^{\mathrm{b}} \pm 0.38(90)$ & $18.19 \pm 0.65(72)$ \\
\hline Third & $2.20 \pm 0.05(106)$ & $9.35^{\mathrm{b}} \pm 0.26(83)$ & $12.98^{\mathrm{b}} \pm 0.32(74)$ & $15.81^{\mathrm{b}} \pm 0.43(65)$ & $19.40 \pm 0.70(60)$ \\
\hline Fourth & $2.18 \pm 0.05(77)$ & $9.11^{\mathrm{b}} \pm 0.30(63)$ & $12.37^{\mathrm{b}} \pm 0.39(51)$ & $15.88^{\mathrm{b}} \pm 0.52(44)$ & $19.66 \pm 0.87(39)$ \\
\hline Fifth & $2.23 \pm 0.07(40)$ & $8.02^{a} \pm 0.39(37)$ & $11.53^{\mathrm{a}} \pm 0.50(30)$ & $13.28^{\mathrm{a}} \pm 0.69(24)$ & $17.61 \pm 1.25(18)$ \\
\hline $\begin{array}{l}\text { Sixth and } \\
\text { above }\end{array}$ & $2.20 \pm 0.08(37)$ & $9.15^{\mathrm{b}} \pm 0.41(33)$ & $12.11^{\mathrm{b}} \pm 0.54(25)$ & $15.61^{\mathrm{b}} \pm 0.72(22)$ & $19.67 \pm 1.16(21)$ \\
\hline
\end{tabular}

* Significant $(\mathrm{P}<0.05) * *$ Highly significant $(\mathrm{P}<0.01)$. Means bearing same superscript don’t differ significantly $(\mathrm{P}>0.05)$. Figures in parentheses are number of observations. 
Analysis of variance showed that the pre-weaning average daily weight gain was highly significantly affected by period, season, type of birth, sex and parity. However, post-weaning growth efficiency was influenced by period $(\mathrm{P}<0.01)$ and season $(\mathrm{P}<0.05)$ alone and other factors had no effect $(\mathrm{P}>0.05)$ on this trait (Table 2). The highest pre- and post-weaning average daily weight gains were observed in period three (1996 - 1999). The difference in rate of weight gain per day of single-born kids compared to multiple born kids was $8.97 \mathrm{~g}$ up to weaning but $1.20 \mathrm{~g}$ by 12 months of age, the latter being not significant $(\mathrm{P}>0.05)$. The overall pre-weaning ADG in this study was lower than the estimates reported by Thiruvenkadan et al. (2007). The efficiency of pre-weaning growth decreased with the parity/age of dam up to the second parity. The efficiency of growth measured in terms of the gain in body weight per kg of initial weight decreased with advancing age. The $1.77 \mathrm{~kg}$ (56.9\%) reduction in growth efficiency during post-weaning development as against the pre-weaning stage indicated that the maximum growth rate had occurred during the preweaning stage.

Table 2 Least-squares means ( \pm s.e.) of average daily weight gain and growth efficiency during pre- and post-weaning stages

\begin{tabular}{|c|c|c|c|c|}
\hline Effect & $\begin{array}{l}\text { Pre-weaning ADG } \\
\text { (WADG) (g) }\end{array}$ & $\begin{array}{l}\text { Post-weaning ADG } \\
\text { (PADG) (g) }\end{array}$ & $\begin{array}{c}\text { Pre-weaning } \\
\text { growth efficiency }\end{array}$ & $\begin{array}{l}\text { Post-weaning } \\
\text { growth efficiency }\end{array}$ \\
\hline Overall & $72.41 \pm 1.68(485)$ & $37.46 \pm 1.49$ (302) & $3.11 \pm 0.08$ (485) & $1.34 \pm 0.05(302)$ \\
\hline Period & $* *$ & $* *$ & $* *$ & $* *$ \\
\hline $\mathrm{P}_{1}(1988-1991)$ & $86.86^{\mathrm{b}} \pm 5.56(21)$ & $34.81^{\mathrm{a}} \pm 4.73(15)$ & $3.65^{\mathrm{b}} \pm 0.27(21)$ & $1.16^{a} \pm 0.17(15)$ \\
\hline $\mathrm{P}_{2}(1992-1995)$ & $61.41^{\mathrm{a}} \pm 3.30(56)$ & $36.05^{\mathrm{a}} \pm 2.48(51)$ & $2.78^{\mathrm{a}} \pm 0.16(56)$ & $1.42^{\mathrm{b}} \pm 0.09(51)$ \\
\hline $\mathrm{P}_{3}(1996-1999)$ & $92.79^{\mathrm{c}} \pm 2.40(121)$ & $43.01^{\mathrm{c}} \pm 1.94(102)$ & $3.86^{\mathrm{b}} \pm 0.11(121)$ & $1.18^{\mathrm{a}} \pm 0.07(102)$ \\
\hline $\mathrm{P}_{4}(2000-2003)$ & $59.93^{\mathrm{a}} \pm 1.92(179)$ & $34.30^{\mathrm{a}} \pm 1.83(98)$ & $2.45^{\mathrm{a}} \pm 0.09$ (179) & $1.26^{\mathrm{a}} \pm 0.06(98)$ \\
\hline$P_{5}(2004-2007)$ & $61.05^{\mathrm{a}} \pm 2.45(108)$ & $39.13^{\mathrm{b}} \pm 2.97(36)$ & $2.81^{\mathrm{a}} \pm 0.12(108)$ & $1.69^{c} \pm 0.10(36)$ \\
\hline Season & $* *$ & $*$ & $* *$ & \\
\hline Winter (Dec. to Feb.) & $63.81^{\mathrm{a}} \pm 2.32(166)$ & $35.58^{\mathrm{a}} \pm 2.09(104)$ & $2.62^{\mathrm{a}} \pm 0.11(166)$ & $1.38 \pm 0.07(104)$ \\
\hline $\begin{array}{l}\text { Summer (Mar. to } \\
\text { May) }\end{array}$ & $76.44^{\mathrm{b}} \pm 2.89(95)$ & $36.29^{\mathrm{a}} \pm 2.69(53)$ & $3.44^{\mathrm{b}} \pm 0.14(95)$ & $1.31 \pm 0.09$ (53) \\
\hline $\begin{array}{l}\text { South-west monsoon } \\
\text { (June to Aug.) }\end{array}$ & $83.17^{\mathrm{C}} \pm 2.97(80)$ & $43.00^{\mathrm{a}} \pm 2.44(65)$ & $3.59^{\mathrm{b}} \pm 0.14(80)$ & $1.42 \pm 0.08(65)$ \\
\hline $\begin{array}{l}\text { North-east monsoon } \\
\text { (Sep. to Nov.) }\end{array}$ & $66.20^{\mathrm{a}} \pm 2.30(144)$ & $34.97^{\mathrm{a}} \pm 2.11(80)$ & $2.79^{\mathrm{a}} \pm 0.11(144)$ & $1.26 \pm 0.07(80)$ \\
\hline Type of birth & $* *$ & & & \\
\hline Single & $76.89^{\mathrm{b}} \pm 2.03(281)$ & $38.06 \pm 1.83(177)$ & $3.07 \pm 0.10(281)$ & $1.28 \pm 0.06(177)$ \\
\hline Multiple born & $67.92^{\mathrm{a}} \pm 2.06(204)$ & $36.86 \pm 1.81(125)$ & $3.15 \pm 0.10(204)$ & $1.40 \pm 0.06(125)$ \\
\hline Sex of the kid & $* *$ & & & \\
\hline Male & $76.25^{\mathrm{b}} \pm 1.97(251)$ & $39.05 \pm 1.82(137)$ & $3.11 \pm 0.09(251)$ & $1.34 \pm 0.06(137)$ \\
\hline Female & $68.56^{\mathrm{a}} \pm 2.05(234)$ & $35.87 \pm 1.77(165)$ & $3.11 \pm 0.10(234)$ & $1.34 \pm 0.06(165)$ \\
\hline Parity & $* *$ & & & \\
\hline First & $66.37 \pm 2.25(151)$ & $37.18 \pm 1.98(93)$ & $3.03 \pm 0.11(151)$ & $1.39 \pm 0.07(93)$ \\
\hline Second & $70.87 \pm 2.48(118)$ & $36.92 \pm 2.23(71)$ & $3.01 \pm 0.12(118)$ & $1.40 \pm 0.08(71)$ \\
\hline Third & $78.95 \pm 2.86(83)$ & $37.37 \pm 2.37(60)$ & $3.28 \pm 0.14(83)$ & $1.25 \pm 0.08(60)$ \\
\hline Fourth & $76.35 \pm 3.30(63)$ & $40.73 \pm 294$ (39) & $3.14 \pm 0.16(63)$ & $1.46 \pm 0.10$ (39) \\
\hline Fifth & $64.55 \pm 4.21(37)$ & $35.10 \pm 4.23(18)$ & $2.75 \pm 0.20(37)$ & $1.31 \pm 0.15$ \\
\hline Sixth and above & $77.36 \pm 4.45$ (33) & $37.48 \pm 3.92(21)$ & $3.46 \pm 0.22(33)$ & $1.24 \pm 0.14(21)$ \\
\hline
\end{tabular}

* Significant $(\mathrm{P}<0.05) * *$ Highly significant $(\mathrm{P}<0.01)$. Means bearing same superscript don’t differ significantly $(\mathrm{P}>0.05)$. Figures in parentheses are number of observations.

The genetic and phenotypic correlations and heritability estimates along with their standard errors are presented in Table 3. The heritability of body weight tended to increase with increasing age from birth to six months and then decreased. Weight at birth was of low heritability $(0.062 \pm 0.069)$ and the heritabilities of the body weights at three, six, nine and 12 months of age were medium to highly heritable. The heritability 
estimates for Tellicherry kids observed are in accordance with earlier reports (Acharya \& Malik, 1971; Bhadula \& Bhat, 1980; Mandal et al., 2003). The low heritability estimate observed for birth weight may be explained by the poor nutritional level of the does ,creating a large environmental variation. The increasing heritability of body weights at the later stages of developmental process indicates that environmental factors had more influence on birth weight than on the weights achieved later in the developmental stages (Mandal et al., 2003). The heritability estimates for gain in weight during the pre- and post-weaning stages of development were $0.285 \pm 0.118$ and $0.385 \pm 0.165$, respectively, and the estimates for efficiency of growth at pre- and post-weaning ages were $0.224 \pm 0.100$ and $0.246 \pm 0.201$, respectively. The phenotypic correlations of birth weight with the body weights at subsequent ages ranged from low to intermediate and were positive $(0.159$ - 0.336). The six-month body weight had a significant, positive and high genetic correlation with the nine and 12 months body weight. This indicated that selection for increased body weight at this age would result in genetic improvement in the subsequent ages.

Table 3 Estimates of heritability (diagonal), genetic correlation (above diagonal) and phenotypic correlation (below diagonal) of different economic traits of Tellicherry goats

\begin{tabular}{|c|c|c|c|c|c|}
\hline Age & Birth & 3 months & 6 months & 9 months & 12 months \\
\hline Birth & $\begin{array}{c}0.062 \pm 0.069 \\
(566)\end{array}$ & $0.685 \pm 0.526$ & $0.378 \pm 0.417$ & $0.291 \pm 0.455$ & $0.075 \pm 0.362$ \\
\hline 3 months & $0.314 \pm 0.168$ & $\begin{array}{c}0.344 \pm 0.163 \\
(485)\end{array}$ & $0.816 \pm 0.113$ & $0.611 \pm 0.164$ & $0.882 \pm 0.238$ \\
\hline 6 months & $0.336 \pm 0.169$ & $0.781 \pm 0.286$ & $\begin{array}{c}0.369 \pm 0.158 \\
(411)\end{array}$ & $0.640 \pm 0.056$ & $0.887 \pm 0.141$ \\
\hline 9 months & $0.256 \pm 0.114$ & $0.703 \pm 0.301$ & $0.913 \pm 0.458$ & $\begin{array}{c}0.298 \pm 0.114 \\
(358)\end{array}$ & $0.939 \pm 0.085$ \\
\hline 12 months & $0.159 \pm 0.110$ & $0.545 \pm 0.212$ & $0.802 \pm 0.356$ & $0.886 \pm 0.414$ & $0.227 \pm 0.110$ \\
\hline
\end{tabular}

(304)

Figures in parentheses are number of observations.

\section{Conclusions}

Period and season of birth, type of birth and sex of the kids were the major factors affecting growth rate of Tellicherry goats. The effect of birth month suggests that planning kidding season would improve production efficiency. The heritability estimates indicated that selection for weight and weight gain should be done on the basis of the post-weaning traits preferably on six months body weight. A positive response could be expected in other traits owing to the generally high and positive correlations. The selection for weight at a later stage would be expected to lead to increased yearling weights, which is desirable in meat animals, although it may be associated with increased maintenance costs.

\section{References}

Acharya, R.M., 1982. Sheep and Goat Breeds of India. FAO Animal Production and Health Paper 30, Food and Agriculture Organisation of the United Nations, Rome, pp viii +190.

Acharya, R.M. \& Malik, R.C., 1971. Genetic and phenotypic parameters for pre- and post-weaning body weight in Nali and Lohi and their crosses with Nellore and Mandya. Indian J. Anim. Sci. 41, 1126-1129.

Bhadula, S.K. \& Bhat, P.N., 1980. Genetic and non-genetic factors affecting body weights in Muzaffarnagari sheep and their half breds. Indian J. Anim. Sci. 50, 852-856.

Bobhate, S.D., Barbind, R.P. \& Hanmante, A.A., 2003. Factors causing variation in birth weight of goats. Indian J. Small Rumin. 9, 173-175.

Harvey, W.R., 1990. User's Guide for LSMLMW and MIXMDL PC-2 Version. Mixed model least-squares and maximum likelihood computer program. Ohio State University, Columbus, Ohio, U.S.A.

Mandal, A., Pant, K.P., Nandy, P.K., Rout, P.K. \& Roy, R., 2003. Genetic analysis of growth traits in 
Muzaffarnagari sheep. Trop. Anim. Hlth. Prod. 35, 271-284.

Meyer, K., 2000. DFREML Programs to estimate variance components by restricted maximum likelihood using a derivative-free algorithm-User Notes.

Mukundan, G., Bhat, P.N. \& Santiago., 1980. Note on genetic study of post-weaning body weights in Malabari breed of goat and its Saanen half breds. Indian J. Anim. Genet. Breed. 2, 90-94.

Sharma, M.C. \& Pathodiya, O.P., 2006. Genetic analysis of relative growth rates in Sirohi kids under field condition. Indian J. Small Rumin. 12, 56-60.

Sivakumar, T. \& Thiagarajan, M., 1999. Growth rate and growth production in Madras Red lambs and Tellicherry kids. Cheiron 28, 140-147.

Thiruvenkadan, A.K., Purushothaman, M.R., Karunanithi, K. \& Singh, G., 2007. Husbandry practices for Mecheri sheep in its breeding tract of Tamil Nadu. Indian J. Anim. Sci. 77, 489-493.

Yadav, J.S., Rai, B., Singh, M.K., Yadav, M.C. \& Khan, B.U., 2003. Factors affecting body weights at different ages in flock of Kutchi goats. India J. Small Rumin. 9, 53-55. 